Article

\title{
Effect of Compost and Titanium Dioxide Application on the Vegetative Yield and Essential Oil Composition of Coriander
}

\author{
Rania M. R. Khater ${ }^{1}$, Reham M. Sabry ${ }^{2}$, Luisa Pistelli ${ }^{3}$, Ahmed M. Abd-ElGawad ${ }^{4,5, *(\mathbb{C}, \text { Walid Soufan }}{ }^{5}$ \\ and Abdel Nasser G. El-Gendy ${ }^{2, *}$
}

1 Medicinal and Aromatic Plants Department, Desert Research Center, El-Matareya, Cairo 11753, Egypt; dr.raniakhater@yahoo.com

2 Medicinal and Aromatic Plants Research Department, Pharmaceutical and Drug Industries Research Institute, National Research Centre, EL-Behouth St., Dokki, Giza 12622, Egypt; rehamsabry2000@hotmail.com

3 Department of Pharmacy, University of Pisa, Via Bonanno 33, 56126 Pisa, Italy; luisa.pistelli@farm.unipi.it

4 Department of Botany, Faculty of Science, Mansoura University, Mansoura 35516, Egypt

5 Plant Production Department, College of Food and Agriculture Sciences, King Saud University, P.O. Box 2460, Riyadh 11451, Saudi Arabia; wsoufan@ksu.edu.sa

* Correspondence: aibrahim2@ksu.edu.sa (A.M.A.-E.); ag.el-gendy@nrc.sci.eg (A.N.G.E.-G.); Tel.: +966-562680864 (A.M.A.-E.); +20-1090077136 (A.N.G.E.-G.)

check for

updates

Citation: Khater, R.M.R.; Sabry, R.M.; Pistelli, L.; Abd-ElGawad, A.M.; Soufan, W.; El-Gendy, A.N.G. Effect of Compost and Titanium Dioxide Application on the Vegetative Yield and Essential Oil Composition of Coriander. Sustainability 2022, 14, 322. https://doi.org/10.3390/su14010322

Academic Editor: Bernhard Huchzermeyer

Received: 6 December 2021

Accepted: 27 December 2021

Published: 29 December 2021

Publisher's Note: MDPI stays neutral with regard to jurisdictional claims in published maps and institutional affiliations.

Copyright: (c) 2021 by the authors. Licensee MDPI, Basel, Switzerland. This article is an open access article distributed under the terms and conditions of the Creative Commons Attribution (CC BY) license (https:// creativecommons.org/licenses/by/ $4.0 /)$.

\begin{abstract}
Coriander is one of the most popular and intensely used spices owing to its multipurpose uses worldwide. It is mainly cultivated for the production of its dried seed and fresh leaves. The present study aimed to evaluate the application of compost and foliar spraying of $\mathrm{TiO}_{2}$ on the yield and essential oil composition of coriander. Two field experiments were conducted during two successive seasons; after that, the yield parameters were determined, and the essential oil of the seeds was extracted and analyzed via gas chromatography-mass spectrometry (GC-MS). Results indicated that coriander growths at both years were significantly affected by compost application and foliar application of $\mathrm{TiO}_{2}$, and a significant interaction of these two factors also occurred. Compost application at $50 \mathrm{~m}^{3}$ caused significant increments of $55 \%$ and $46 \%$ in umbels number and $75 \%$ and $64 \%$ in seed yield in the first and second season, respectively, compared with control. The application of compost to the coriander plant significantly influenced oil percentage and oil yield per ha. The maximum oil percent was recorded in control plants. Foliar application of $\mathrm{TiO}_{2}$ resulted in significant improvement in plant height, number of umbels, and seed yield of coriander as compared with control and reached their maximum values at $6 \mathrm{~g} \mathrm{~L}^{-1}$ compared with the control; foliar application of $\mathrm{TiO}_{2}$ at $2 \mathrm{~g} \mathrm{~L}^{-1}$ enhanced numbers of umbels by $22 \%$ with no significant differences between 2,4 , and $6 \mathrm{~g} \mathrm{~L}^{-1}$ treatments in the first season and by 24,33 , and $48 \%$ in the second season. Increases in seed yield accounted for 34,43 , and $64 \%$ in the first season and 21,36 , and $45 \%$ in the second season due to titanium dioxide application of 2,4 , and $6 \mathrm{~g} \mathrm{~L}^{-1}$, respectively. The maximum content of linalool $(87.61 \%)$ and minimum content of estragole $(0.7 \%)$ was recorded at $4 \mathrm{~g} \mathrm{~L}^{-1}$ titanium dioxide with no compost.
\end{abstract}

Keywords: Coriandrum sativum L.; soil fertility; $\mathrm{TiO}_{2}$; essential oil; linalool

\section{Introduction}

Coriander (Coriandrum sativum L.) is an annual herb and belongs to the Apiaceae family and its origin in the Mediterranean basin. It is one of the most popular and intensely used spices owing to its multipurpose uses all over the world. Coriander is mainly cultivated for the production of its dried seed and fresh leaves as a spice, which are the most common parts used for cooking. The unique flavour of coriander makes it an attractive ingredient that finds applications in many popular dishes and curry powder and makes it a good preservative in food processing [1]. 
Coriander foliage contains carbohydrates, proteins, fibres, vitamins, and minerals (calcium, phosphorus, and iron), making it valuable for human nutrition. Both the seeds and flowering stems contain essential oil (range from $0.03-2.6 \%$ ) that is usually extracted by hydrodistillation and is characterized by the presence of linalool as the main component, which typically constitutes more than $50 \%$ of the total essential oil of seeds [2,3]. Chemical analysis revealed the presence of monoterpenes, limonene, $\alpha$-pinene, $\delta$-terpinene, p-cymene, citronellol, borneol, camphor, coriandrin, geraniol, dihydrocoriandrin, and coriandrons A-E in their essential oil [3]. The characteristic smell is generated by different aldehydic components of the essential oil present in the herb [4].

Aside from the nutritional values of coriander as a vegetable, it possesses pharmacological properties that have been associated with positive health outcomes. The value of coriander as a medicinal plant was examined previously by several authors. Pathak Nimish et al. [5] highlighted the antioxidant, anti-diabetic, anti-mutagenic, and anthelmintic activities. Some evidence was also found regarding hypnotic, anticonvulsant, and diuretic activities. In addition, different parts of coriander (leaves, seeds, and flowers) are effective for reducing cholesterol and playing protecting role against heavy metal toxicity. Its essential oil is commonly utilized in aromatherapy since it can act as a sedative or for nervous system relief. The health effects of the essential oil can be summarized in the anticancer, anxiolytic, hepatoprotective, post-coital, and anti-fertility properties [6]. In addition, anti-protozoal and anti-ulcer activities of coriander have been reported [7]. Coriander has strong spasmolytic and local anesthetic effects. It is also used as a topical remedy against many skin complaints, mostly in the form of tea tree oil. The antioxidant [3], anti-diabetic [8], anti-cancerous, and antimutagenic effects [9] are attributed to the essential oil and various extracts from coriander fruits. Moreover, it can act as an anti-bacterial and anti-fungal agent.

Organic fertilization attracts the attention of researchers in both developed and developing countries during the current decades due to the growing awareness about health risks associated with improper application of chemical fertilizers and their detrimental effects on the environment and the physicochemical and biological properties of the soil. In addition, there has been an increased demand for herbs and spices produced under organic fertilization. Organic fertilizers, including farmyard manure, compost, and vermicompost, deliver nutrients for plants to ensure high-quality economic yield without offsetting negative environmental impacts. Compost as a source of organic fertilizer is characterized by a high organic matter content as well as abundance in macro-and micronutrients. Besides its role in plant yield enhancement, compost presents better physical and chemical properties of soil, for example, soil structure, soil aggregation, porosity, hydraulic conductivity, air exchange, water holding capacity, soil pH, and microbial activity. Further, compost lowers bulk density and restores soil organic carbon and nitrogen. Organic fertilizers have a slower release rate than mineral ones $[10,11]$.

One of the modern agricultural approaches to improve the growth and yield of plants include using titanium-containing fertilizers. Titanium (Ti) is thought to be a beneficial element for plants and can be found at low concentrations (0.1-10 ppm). Titanium is difficult to be extracted by plants because it occurs mostly as insoluble in water between 3-8 pH, as it starts to hydrolyze and convert into insoluble forms [12]. Early studies on Tienriched fertilizers focused on their stimulatory effects on plant growth, yield, and quality of some species. Foliar spraying with bulk or nanoparticles titanium had positive effects on biochemical components and some active substances of moringa leaves, stimulating photosynthesis and plant growth and boosting chlorophyll a and b biosynthesis [13].

More recently, similar improvements in seed germination, radicle and plumule growth in canola seedlings, and growth of wheat plants under drought conditions in response to applications of low levels of titanium through roots or leaves have been reported. It competes with some essential elements for adsorption on their binding sites of soils (probably mainly from the phosphate-based ones). Interestingly, several studies demonstrate that titanium at low concentrations may exert beneficial effects in higher plants, such as 
improving plant physiology, activation of specific enzymes (glutamate dehydrogenase, nitrate reductase, glutamine synthase, etc.), improving chlorophyll content and manner of photosynthesis, boosting nutrient uptake, conferring tolerance against oxidative stress through helping the plant to incorporate more nutrients, synthesizing more metabolites, encouraging absorption of nitrates, and encouraging the transformation of inorganic nitrogen into organic nitrogen, such as protein and chlorophyll [14]. Similar studies have not yet been conducted on organic fertilizers and titanium on coriander; thus, this study is a substantial attempt to enhance or manipulate biomass and essential oil content of coriander plants throughout compost and titanium dioxide application.

\section{Materials and Methods}

\subsection{Site Description, Soil and Compost Properties}

Two field experiments were performed during the 2017-2018 and 2018-2019 growing seasons at the Baluza Research Station, Desert Research Center, North Sinai governorate to study the effect of compost and titanium dioxide application on biomass, essential oil content, and composition of coriander plants. Soil analysis and compost properties were provided in Tables S1 and S2.

\subsection{Layout and Design of the Experiment}

Seeds of coriander (Coriandrum sativum L.) were planted directly in their final position in the second week of October 2017 and 2018. The experimental design was a randomized complete block with three replicates. Three compost rates $\left(0,50\right.$, and $\left.70 \mathrm{~m}^{3} \mathrm{ha}^{-1}\right)$ and four titanium dioxide concentrations $\left(0,2,4\right.$, and $\left.6 \mathrm{~g} \mathrm{~L}^{-1}\right)$ were assigned randomly in plots. Titanium dioxide was dissolved in distilled water and sprayed directly on the plants 3 times along each season starting 45 days after planting (one month between applications). Compost was applied before planting. Each plot consisted of four rows, $70 \mathrm{~cm}$ apart, and the distance between plants in the row was $30 \mathrm{~cm}$. Irrigation, plant protection, and weed control were carried out when necessary. At harvest, plant height, umbels number, seed yield ( $t /$ ha), oil percent, and oil yield (L/ha) were recorded.

\subsection{Extraction and Analysis of Basil Essential Oils}

Coriander essential oil was extracted from seeds through hydro-distillation method using Clevenger's apparatus according to Guenther [15]. Essential oil percentage was estimated as $(\mathrm{V} / \mathrm{W})$ with the following equation:

$$
\% \text { Essential oil }=\mathrm{V} \times 100 / \mathrm{W}
$$

$\mathrm{V}=$ volume of oil after extraction; $\mathrm{W}=$ Weight of coriander seeds used for extraction; Oil yield $\mathrm{L} / \mathrm{ha}=(\%$ Essential oil $\times$ seeds yield $\mathrm{kg} / \mathrm{ha}) / 100$.

The extracted oil was dried using anhydrous sodium sulphate and subsequently preserved in sealed glass vials at $4{ }^{\circ} \mathrm{C}$ for the gas chromatography-mass spectrometry (GC-MS) analysis.

\subsection{Statistical Analysis}

In each season, the data were subjected to the analysis of variance in Randomized Complete Block Design (RCBD) by using MSTAT-C V.2.1 software package for each season separately according to procedures reported by Gomez and Gomez [16]. Differences among means were compared for each trait using the least significant differences test (LSD).

\section{Results and Discussion}

Analysis of variance showed that coriander growth and yield were significantly affected by compost application and foliar application of titanium dioxide, and a significant interaction of these two factors also occurred in both seasons (Tables 1 and 2). 
Table 1. Effect of compost and titanium dioxide on plant height, umbels no., seed yield, oil percentage, and oil yield of coriander during the first season.

\begin{tabular}{cccccc}
\hline Treatments & $\begin{array}{c}\text { Plant Height } \\
(\mathbf{c m})\end{array}$ & $\begin{array}{c}\text { Umbels No. } \\
\mathbf{( 1 0 0 0 / h a )}\end{array}$ & $\begin{array}{c}\text { Seed Yield } \\
\mathbf{( k g / h a )}\end{array}$ & $\begin{array}{c}\text { Oil Yield } \\
\mathbf{( \% )}\end{array}$ & $\begin{array}{c}\text { Oil Yield } \\
\text { (L/ha) }\end{array}$ \\
\hline C0 & 56.73 & 966.66 & 1335.15 & 0.37 & 5.01 \\
C1 & 86.17 & 1494.43 & 2334.26 & 0.35 & 8.05 \\
C2 & 98.27 & 1694.43 & 2757.20 & 0.30 & 7.87 \\
\hline LSD 5\% & 4.87 & 174.93 & 190.62 & 0.0113 & 0.8625 \\
\hline T0 & 64.72 & 1170.36 & 1575.91 & 0.36 & 5.78 \\
T1 & 80.08 & 1429.62 & 2113.16 & 0.38 & 8.11 \\
T2 & 84.41 & 1451.84 & 2289.98 & 0.30 & 6.33 \\
T3 & 92.35 & 1488.88 & 2589.75 & 0.31 & 7.69 \\
\hline LSD 5\% & 2.96 & 96.15 & 130.27 & 0.0099 & 0.6016 \\
\hline C0T0 & 42.23 & 777.77 & 842.21 & 0.33 & 2.78 \\
C0T1 & 54.27 & 1022.21 & 1231.54 & 0.34 & 4.19 \\
C0T2 & 62.23 & 1066.66 & 1537.98 & 0.4 & 6.15 \\
C0T3 & 68.2 & 999.99 & 1728.87 & 0.4 & 6.92 \\
C1T0 & 74.11 & 1288.88 & 1939.98 & 0.34 & 6.60 \\
C1T1 & 86.38 & 1511.1 & 2139.31 & 0.4 & 8.56 \\
C1T2 & 88.04 & 1555.54 & 2330.87 & 0.28 & 6.53 \\
C1T3 & 96.13 & 1622.21 & 2926.86 & 0.36 & 10.54 \\
C2T0 & 77.81 & 1444.43 & 1945.54 & 0.41 & 7.98 \\
C2T1 & 99.58 & 1755.54 & 2968.64 & 0.39 & 11.58 \\
C2T2 & 102.96 & 1733.32 & 3001.08 & 0.21 & 6.30 \\
C2T3 & 112.73 & 1844.43 & 3113.53 & 0.18 & 5.60 \\
\hline LSD 5\% & 5.13 & 140.35 & 225.64 & 0.017 & 1.042 \\
\hline C0 & & & & \\
\hline
\end{tabular}

$\mathrm{C} 0$, without compost; $\mathrm{C} 1,50 \mathrm{~m}^{3}$ compost ha ${ }^{-1} ; \mathrm{C} 2,70 \mathrm{~m}^{3}$ compost ha ${ }^{-1} ; \mathrm{T} 0$, zero $\mathrm{TiO}_{2} ; \mathrm{T} 1,2 \mathrm{gL}^{-1} \mathrm{TiO} 2 ; \mathrm{T}_{2}, 4 \mathrm{TiO}_{2}$; $\mathrm{T} 3,6 \mathrm{gL}^{-1} \mathrm{TiO}_{2}$.

Table 2. Effect of compost and titanium dioxide on plant height, umbels no., seed yield, oil percentage, and oil yield of coriander during the second season.

\begin{tabular}{cccccc}
\hline Treatments & $\begin{array}{c}\text { Plant Height } \\
(\mathbf{c m})\end{array}$ & $\begin{array}{c}\text { Umbels No. } \\
\mathbf{( 1 0 0 0 / h a )}\end{array}$ & $\begin{array}{c}\text { Seed Yield } \\
\mathbf{( k g / h a )}\end{array}$ & $\begin{array}{c}\text { Oil Yield } \\
\mathbf{( \% )}\end{array}$ & $\begin{array}{c}\text { Oil Yield } \\
\text { (L/ha) }\end{array}$ \\
\hline C0 & 62.51 & 1083.32 & 1575.21 & 0.38 & 6.05 \\
C1 & 90.48 & 1583.32 & 2585.81 & 0.34 & 8.82 \\
C2 & 103.67 & 2049.98 & 2956.14 & 0.29 & 8.27 \\
\hline LSD 5\% & 4.54 & 59.73 & 51.46 & 0.0507 & 1.154 \\
\hline T0 & 68.28 & 1244.43 & 1891.91 & 0.36 & 6.87 \\
T1 & 85.49 & 1548.13 & 2283.24 & 0.38 & 8.70 \\
T2 & 91.77 & 1651.84 & 2568.71 & 0.29 & 7.07 \\
T3 & 96.69 & 1844.43 & 2745.68 & 0.31 & 8.20 \\
\hline LSD 5\% & 3.64 & 95.3 & 78.85 & 0.0099 & 3.68 \\
\hline C0T0 & 45.21 & 866.66 & 1051.33 & 0.35 & 4.85 \\
C0T1 & 62.59 & 1066.66 & 1385.32 & 0.35 & 7.27 \\
C0T2 & 69.52 & 1155.54 & 1818.65 & 0.4 & 8.39 \\
C0T3 & 72.74 & 1244.43 & 2045.54 & 0.41 & 7.43 \\
C1T0 & 77.66 & 1333.32 & 2185.09 & 0.34 & 9.79 \\
C1T1 & 90.18 & 1577.76 & 2446.65 & 0.4 & 7.96 \\
C1T2 & 93.83 & 1622.21 & 2744.64 & 0.29 & 10.09 \\
C1T3 & 100.26 & 1799.98 & 2966.86 & 0.34 & 9.51 \\
\hline
\end{tabular}


Table 2. Cont.

\begin{tabular}{cccccc}
\hline Treatments & $\begin{array}{c}\text { Plant Height } \\
(\mathbf{c m})\end{array}$ & $\begin{array}{c}\text { Umbels No. } \\
(\mathbf{1 0 0 0 / h a )}\end{array}$ & $\begin{array}{c}\text { Seed Yield } \\
\mathbf{( k g / h a )}\end{array}$ & $\begin{array}{c}\text { Oil Yield } \\
\mathbf{( \% )}\end{array}$ & $\begin{array}{c}\text { Oil Yield } \\
\text { (L/ha) }\end{array}$ \\
\hline C2T0 & 81.98 & 1533.32 & 2439.31 & 0.39 & 11.47 \\
C2T1 & 103.7 & 1999.98 & 3017.75 & 0.38 & 5.97 \\
C2T2 & 111.95 & 2177.76 & 3142.86 & 0.19 & 6.13 \\
C2T3 & 117.06 & 2488.86 & 3224.63 & 0.19 & 3.68 \\
\hline LSD 5\% & 9.12 & 165.07 & 136.58 & 0.017 & 0.713 \\
\hline
\end{tabular}

$\mathrm{C} 0$, without compost; $\mathrm{C} 1,50 \mathrm{~m}^{3}$ compost ha ${ }^{-1} ; \mathrm{C} 2,70 \mathrm{~m}^{3}$ compost ha ${ }^{-1} ; \mathrm{T} 0$, zero $\mathrm{TiO}_{2} ; \mathrm{T} 1,2 \mathrm{gL}^{-1} \mathrm{TiO} 2 ; \mathrm{T} 2,4 \mathrm{TiO}_{2}$ $\mathrm{T} 3,6 \mathrm{gL}^{-1} \mathrm{TiO}_{2}$.

\subsection{Effect of Compost}

Application of compost fertilizer significantly affected coriander plant height, umbels number, seed yield ( $t / h a)$, oil percent (\%), and oil yield (L/ha). Compost application resulted in significant increase in plant height, number of umbels per 1000/ha, and seed yield of coriander as compared with control and in reaching their maximum values at $70 \mathrm{~m}^{3} \mathrm{ha}^{-1}$.

Increase in compost dose from zero to $50 \mathrm{~m}^{3} \mathrm{ha}^{-1}$ caused significant increments in umbels number $(55 \%, 46 \%)$ and seed yield $(75 \%, 64 \%)$ in the first and second season, respectively, whilst enhancement of compost dose from 50 to $70 \mathrm{~m}^{3}$ caused significant increments of $13 \%$ and $29 \%$ in umbels number and $18 \%$ and $14 \%$ in seed yield in the first and second season, respectively.

The application of compost to the coriander plant significantly influenced oil percent (\%) and oil yield per ha. The maximum oil percent was recorded in control plants (unfertilized with compost). Perhaps due to this, a lesser amount of fertilizer is needed for growing coriander, and adding too much fertilizer may lead to the dilution of flavor of leaves and seeds [17], whereas the maximum essential oil yield was recorded in coriander that received $50 \mathrm{~m}^{3}$, with no significant differences for $70 \mathrm{~m}^{3}$. An increase of $60 \%$ and $46 \%$ in oil yield $\left(\mathrm{L} \mathrm{ha}^{-1}\right)$ after applying $50 \mathrm{~m}^{3}$ compost was noted in the first and second season, respectively, although the application of this rate resulted in a 9 and $12 \%$ decline in oil percent compared to control. On the other hand, raising the compost rate from 50 to $70 \mathrm{~m}^{3} \mathrm{ha}^{-1}$ resulted in a 13 and $17 \%$ decline in oil percent in the first and second season, respectively accompanied by an insignificant reduction in the oil yield. Seed yield increases were largely due to the increased number of umbels per plant and consequently increased essential oil yield per ha.

These results are consistent with those of Lal et al. [11], who demonstrated that vermicompost had significant effects on essential oil content and composition and the maximum essential oil content of coriander $\left(0.41 \mathrm{~g} \mathrm{~kg}^{-1}\right)$ produced from the addition of only $5 \mathrm{t} \mathrm{ha}^{-1}$ vermicompost (the lowest level). Moreover, Darzi [18] reported that adding 6 t ha ${ }^{-1}$ vermicompost provided the highest essential oil content and yield, alpha-pinene percent, and the minimum cymene percent in essential oil. Said-Al Ahl and Khalid [19] investigated the effect of compost application on the fruits essential oil of C. sativum, and they found that the highest percentage of essential oil was recorded when $15 \mathrm{~m}^{3}$ compost per acre was added while spraying tea compost after 45 days and 60 days from the sowing compared with the control treatments.

Like our results, previous research has shown that higher coriander growth and yield attributes were achieved to various organic treatments, such as compost [20], sheep manure, and vermicompost [21-23]. Applying $20 \mathrm{~m}^{3} /$ feddan compost and 15-20 $\mathrm{t} \mathrm{ha}^{-1}$ vermicompost yielded the best herbage, seed yield, seed weight, oil percentage, oil yield (L/feddan), total nitrogen and carbohydrate percentages, and essential oil composition [24,25]. Vermicompost at 9 ton/ha offered the highest fresh and dry weights of plant and biomass yield [26]. Increasing growth and yield parameters with increasing compost rates may be due to the increasing uptake of nutrients by coriander and the availability of $\mathrm{N}, \mathrm{K}, \mathrm{Cu}, \mathrm{Fe}$, 
and $\mathrm{Mn}$ in soil. Biological carbon sequestration, net biological, and soil carbon were also enhanced [27].

Organic fertilization in our study could have produced similar or even greater yield attributes than that reported by several authors who fertilized coriander with chemical fertilization. The seed yield of coriander of the different treatments averaged from 842 to 3224 compared to 1200-1400 kg per hectare according to Kumar et al. [22] and 607.33$1098.33 \mathrm{~kg} / \mathrm{ha}$ according to Sharangi and Roychowdhury [28]. The number of umbels per plant ranged from 966.66 to 2488.86 (1000/ha). Sharangi and Roychowdhury [28] reported that the application of organic nutrient supplementation for coriander yielded 15.38-25.58 umbel/plant, while Khalid [29] showed that coriander plants treated with NP fertilizers had 29.0 umbel/plant. The positive effect of organic fertilizers may result from faster cell division, multiplication, and cell elongation in the meristematic region of the plant due to production of plant growth-promoting substances, which stimulated the metabolic process of the plant (including increased uptake of nutrients from insoluble nutrients by the activation of desirable enzymes) [22]. For example, organic fertilization promotes a higher production, improvements in soil characteristics, increase in cation exchange capacity, elevation of $\mathrm{pH}$, and maintenance of plant hormones production that stimulate plant development and resistance [30]. The organic sources are directly or indirectly helpful in increasing the availability and uptake of nutrients from the soil and ultimately boosting the yield and quality of coriander without changing the properties of the soil [31]. By contrast, a study by Carrubba and Ascolillo [32] showed significant decline in coriander seed yields with organic fertilization compared to chemical fertilization, and this could be attributed to the low rate of nitrification processes under those climatic conditions.

\subsection{Effect of Foliar Application of Titanium Dioxide}

Foliar application of titanium dioxide had a highly significant $(p<0.001)$ effect on plant height, umbels number, seed yield, oil percent, and oil yield. Foliar application of $\mathrm{TiO}_{2}$ resulted in significant improvement in plant height, number of umbels, and seed yield of coriander as compared with control, and thus, they reached their maximum values at $6 \mathrm{~g} \mathrm{~L}^{-1}$ (Tables 1 and 2). Compared with the control, foliar application of $\mathrm{TiO}_{2}$ at $2 \mathrm{~g} \mathrm{~L}^{-1}$ enhanced numbers of umbels by $22 \%$ with no significant differences among 2,4 , and $6 \mathrm{~g} \mathrm{~L}^{-1}$ concentrations in the first season and by 24,33 , and $48 \%$ in the second season. Compared with the control, increases in seed yield accounted for 34,43 , and $64 \%$ in the first season and 21,36 , and $45 \%$ in the second season due to titanium dioxide application of 2,4 , and $6 \mathrm{~g} \mathrm{~L}^{-1}$, respectively.

An increase in oil percent accounting for $5 \%$ was noticed as titanium dioxide was applied $\left(2 \mathrm{~g} \mathrm{~L}^{-1}\right)$. However, beyond this treatment, a decrease in oil percent was reported where the medium and the higher applications of 4 and $6 \mathrm{~g} \mathrm{~L}^{-1}$ had negative effects on the oil percent in both seasons. Foliar application of $2 \mathrm{~g} \mathrm{~L}^{-1}$ titanium dioxide produced the highest essential oil yield. Compared with the control, increases in oil yield accounted for 40 and $26 \%$ due to titanium dioxide application of $2 \mathrm{~g} \mathrm{~L}^{-1}$ in the first and second season, respectively.

These results confirm the effectiveness of titanium dioxide on enhancing the growth and yield parameters of some plants, as mentioned in very few reports. One of the studies reported that exogenously applied $\mathrm{TiO}_{2} \mathrm{NPs}$ promoted growth characteristics, such as plant height, branches number and fruit yield of coriander [33], aerial parts and root dry weights, leaf area of lemon balm [34], plant height, and shoot fresh and dry weights and root dry weight of Thymus vulgaris [35]. A similar response was proposed by Shabbir et al. [36] while working with Vetiveria zizanioides since shoot and root FM and DM were improved by $\mathrm{TiO}_{2} \mathrm{NPs}$ application at $90 \mathrm{mg} \mathrm{L}^{-1}$. Moreover, another study reported significant increase in growth parameters of fennel plants where $\mathrm{TiO}_{2}$ nanoparticles at $6 \mathrm{ppm}$ gave the highest number of branches, the highest fruit yield per plant and the highest values of pigments, carbohydrates, phosphorus, sugars nitrogen, potassium [37]. The positive effect of titanium dioxide on growth and yield parameters of some plants could be linked to the 
stimulating effect on the metabolic activities, i.e., stomatal conductance, enzyme activities, net photosynthetic, chlorophyll fluorescence, and nutrient status (nitrogen, potassium, and phosphorus) [13,38], enhancing the pigments, carbohydrates, sugars, and aminoacids [37]. At the same time, our results disagreed with those of Missaoui et al. [39] on fenugreek, who stated that there were no significant effects on seedlings' growth and biomass of stem but reported a decrease in the fresh weight of leaves after $\mathrm{TiO}_{2} \mathrm{NPs}$ treatment. Plants treated with $100 \mathrm{mg} \mathrm{L}^{-1}$ of $\mathrm{TiO}_{2} \mathrm{NPs}$ presented a reduction and chlorosis in leaf area due to a significant decrease in the chlorophyll $\mathrm{a}$ and $\mathrm{b}$ contents. The highest value of the photosynthetic pigments was recorded at $50 \mathrm{mg} \mathrm{L}^{-1}$ of $\mathrm{TiO}_{2} \mathrm{NPs}$.

\subsection{Interaction between Compost and Foliar Application of Titanium Dioxide}

As for the interaction effect between compost and foliar application of titanium dioxide, data in Tables 1 and 2 showed that plants treated with $50 \mathrm{~m}^{3} \mathrm{ha}^{-1}$ compost and $6 \mathrm{mg} \mathrm{L}^{-1}$ $\mathrm{TiO}_{2}$ application produced the highest values of plant height, umbels number, and seed yield ( $\mathrm{t} / \mathrm{ha}$ ) in both seasons. Among all treatments studied, the coriander that received the highest dose of compost $\left(70 \mathrm{~m}^{3}\right)$ without any titanium dioxide application produced the highest essential oil percent of coriander seeds in the first season and $6 \mathrm{~g} \mathrm{~L}^{-1}$ titanium dioxide without compost application in the second season than other treatments, while the lowest oil percent was achieved from the two rates of compost $\left(50\right.$ and $70 \mathrm{~m}^{3}$ ) with the highest concentration of titanium dioxide $\left(6 \mathrm{~g} \mathrm{~L}^{-1}\right)$. The maximum increase in oil yield was recorded at $70 \mathrm{~m}^{3}$ compost with $2 \mathrm{~g} \mathrm{~L}^{-1}$ titanium dioxide application. With the highest dose of compost, coriander plants were less responsive to $\mathrm{TiO}_{2}$ application where seed yield did not differ significantly between the 2,4 , and $6 \mathrm{~g} \mathrm{~L}^{-1} \mathrm{TiO}_{2}$ applications in the first season and between the 2 and $4 \mathrm{~g} \mathrm{~L}^{-1}$ and between 4 and $6 \mathrm{~g} \mathrm{~L}^{-1}$ in the second season although the seed yield trend corresponded to the increase in the number of umbels.

\subsection{Essential Oil Composition}

The essential oil profile of the harvested coriander seeds is detailed in Table 4. Overall, 22 components were identified that represented $\sim 99 \%$ of the oil constituents. The main component found in the essential oils is linalool (77.06-87.61\%), followed by $p$-cymene (2.75$4.98 \%)$, $\gamma$-terpinene (1.23-2.05\%), (+)-2-bornanone (1.67-4.55\%), estragole $(0.70-9.84 \%)$, and (-)-carvone $(0.59-2.38 \%)$. Such a profile is similar to the reports of other authors with linalool as the main component $[19,40]$, corresponding with the greater values in our study. The interaction effect of nano- $\mathrm{TiO}_{2}$ and compost application on essential oil composition was significant $(p \leq 0.01)$. The maximum content of linalool $(87.61 \%)$ and minimum content of estragole $(0.70 \%)$ were recorded at $4 \mathrm{~g} \mathrm{~L}^{-1}$ titanium dioxide with no compost. In all titanium dioxide levels, linalool percentage decreased, and estragole contents increased with increasing compost dose. The lowest content of linalool was obtained from plants treated with $70 \mathrm{~m}^{3} \mathrm{ha}^{-1}+6 \mathrm{~g} \mathrm{~L}^{-1}$ titanium dioxide, while the highest content of estragole was obtained from plants treated with $70 \mathrm{~m}^{3}$ without $\mathrm{TiO}_{2}$ application. Elevated levels of linalool and higher levels of estragole with higher compost rates may be due to the fact that compost contains a high content of nitrogen, and the higher nitrogen application increases methyl chavicol concentration and decreases the percentage of linalool in the volatile oil of some aromatic plant species [41]. This is in accordance with the findings of Said-Al Ahl and Khalid [19], who revealed that the highest value of linalool was obtained by the treatment of $15 \mathrm{~m}^{3}$ compost per feddan with the value of $79.23 \%$, while the control treatment gave the highest percentage of $\alpha$-pinene and limonene with the values of $5.86 \%$ and $6.86 \%$. Likewise, vermicompost and inorganic fertilizers had no effect on the oil content and linalool content of coriander [42]. In addition, Shabbir et al. [36] reported that different foliar $\mathrm{TiO}_{2} \mathrm{NPs}$ concentrations noticeably affected the essential oil and khusimol yield of Vetiveria zizanioides, recorded at $300 \mathrm{DAT}$ and $\mathrm{TiO}_{2} \mathrm{NPs}$ at $90 \mathrm{mg} \mathrm{L}^{-1}$ improved essential oil and khusimol contents. In another study by Sayyadizadeh et al. [34] on lemon balm, data showed that the low concentration of dioxide titanium increased essential oil percent. Ahmad et al. [38] also implied this effect in their report of higher quality of Mentha piperita L 
essential oil by $\mathrm{TiO} 2-\mathrm{NPs}$ application, as the menthol component percentage is significantly enhanced. Improved essential oil production might be attributed to the fact that $\mathrm{TiO}_{2}$ has an elicitor effect through jasmonic acid and its methyl-ester signaling. Conversely, some previous studies have shown that titanium dioxide concentration had no effect on the oil content and composition of Thymus vulgaris [35], and they are more likely affected by several factors, such as genetic structure, climatic conditions, soil macro and micronutrient, agricultural applications, and fruit size [43].

Table 3. Relative abundance (\%) of the compounds in seed essential oils of coriander as affected by the treatments of either titanium dioxide or compost application.

\begin{tabular}{|c|c|c|c|c|c|c|c|c|c|c|c|c|c|c|}
\hline \multirow{3}{*}{ No. } & \multirow{3}{*}{ Compound } & \multirow{3}{*}{ Rt } & \multicolumn{8}{|c|}{ Titanium Dioxide } & \multicolumn{4}{|c|}{ Compost } \\
\hline & & & \multicolumn{2}{|c|}{ СоT0 } & \multicolumn{2}{|c|}{ C0T1 } & \multicolumn{2}{|c|}{ C0T2 } & \multicolumn{2}{|c|}{ С0T3 } & \multicolumn{2}{|c|}{ C1T0 } & \multicolumn{2}{|c|}{ C1T1 } \\
\hline & & & $\%$ & SD & $\%$ & SD & $\%$ & SD & $\%$ & SD & $\%$ & SD & $\%$ & SD \\
\hline 1 & Sabinene & 3.33 & 0.12 & 0.01 & 0.13 & 0.01 & 0.10 & 0.01 & 0.13 & 0.01 & 0.13 & 0.01 & 0.09 & 0.01 \\
\hline 2 & $\beta$-Pinene & 3.42 & 0.14 & 0.01 & 0.14 & 0.01 & 0.13 & 0.01 & 0.16 & 0.01 & 0.16 & 0.01 & 0.11 & 0.01 \\
\hline 3 & $\beta$-Myrcene & 3.65 & 0.18 & 0.02 & 0.18 & 0.02 & 0.15 & 0.02 & 0.18 & 0.02 & 0.18 & 0.02 & 0.13 & 0.02 \\
\hline 4 & p-Cymene & 4.49 & 4.14 & 0.20 & 4.72 & 0.30 & 3.79 & 0.20 & 3.45 & 0.01 & 4.33 & 0.10 & 3.84 & 0.30 \\
\hline 5 & Eucalyptol & 4.68 & 0.03 & - & 0.03 & - & 0.02 & 0.01 & 0.02 & 0.01 & 0.02 & 0.01 & 0.03 & - \\
\hline 6 & $\gamma$-Terpinene & 5.29 & 2.04 & 0.10 & 2.05 & 0.20 & 1.47 & 0.10 & 1.97 & 0.10 & 1.97 & 0.1 & 1.51 & 0.2 \\
\hline 7 & Linalool oxide B & 5.85 & 0.30 & 0.01 & 0.4 & 0.10 & 0.31 & 0.01 & 0.28 & 0.01 & 0.28 & 0.01 & 0.24 & 0.10 \\
\hline 8 & Terpinolene & 6.05 & 0.08 & 0.02 & 0.08 & 0.02 & 0.07 & 0.02 & 0.08 & 0.02 & 0.08 & 0.02 & 0.06 & 0.02 \\
\hline 9 & Linalool oxide A & 6.35 & 0.20 & 0.01 & 0.26 & 0.01 & 0.33 & 0.01 & 0.54 & 0.01 & 0.54 & 0.01 & 0.73 & 0.01 \\
\hline 10 & Fenchone & 6.41 & 0.19 & 0.01 & 0.22 & 0.01 & - & - & - & - & - & - & - & - \\
\hline 11 & L-Linalool & 6.88 & 85.54 & 0.50 & 82.98 & 0.40 & 87.61 & 0.30 & 84.33 & 0.25 & 83.74 & 0.50 & 77.34 & 0.70 \\
\hline 12 & $(+)$-2-Bornanone & 8.41 & 3.58 & 0.20 & 3.55 & 0.12 & 4.29 & 0.12 & 3.22 & 0.20 & 3.32 & 0.12 & 2.78 & 0.20 \\
\hline 13 & Citronellal & 8.63 & - & - & 0.13 & 0.02 & - & - & 0.04 & 0.01 & 0.04 & 0.02 & 0.03 & 0.02 \\
\hline 14 & endo-Borneol & 9.39 & 0.31 & 0.01 & 0.76 & 0.01 & 0.26 & 0.01 & 0.49 & 0.01 & 0.49 & 0.10 & 0.32 & 0.01 \\
\hline 15 & Terpinene-4-ol & 9.63 & 0.13 & 0.01 & 0.17 & 0.01 & 0.10 & 0.01 & 0.12 & 0.01 & 0.12 & 0.01 & 0.12 & 0.01 \\
\hline 16 & Estragole & 10.39 & 1.20 & 0.10 & 2.46 & 0.10 & 0.70 & 0.10 & 2.81 & 0.03 & 2.91 & 0.10 & 9.84 & 0.10 \\
\hline 17 & $\beta$-Citronellol & 11.85 & - & - & 0.09 & 0.10 & - & - & - & - & - & - & - & - \\
\hline 18 & (-)-Carvone & 12.38 & 0.91 & 0.20 & 0.59 & 0.20 & - & - & 0.75 & 0.15 & 0.75 & 0.20 & 2.38 & 0.20 \\
\hline 19 & Grandlure II & 12.85 & - & - & 0.11 & 0.01 & 0.10 & 0.01 & 0.08 & 0.01 & 0.08 & 0.01 & - & - \\
\hline 20 & Myrtenyl acetate & 15.25 & 0.04 & 0.01 & 0.05 & 0.01 & - & - & 0.04 & 0.01 & 0.04 & 0.01 & - & - \\
\hline 21 & Geranyl acetate & 17.72 & 0.68 & 0.10 & 0.79 & 0.01 & - & - & 0.76 & 0.01 & 0.76 & 0.01 & 0.38 & 0.01 \\
\hline 22 & Dillapiole & 27.73 & 0.21 & 0.01 & 0.09 & 0.01 & 0.56 & 0.01 & 0.05 & 0.01 & 0.05 & 0.01 & 0.07 & 0.01 \\
\hline \multicolumn{3}{|c|}{ Monoterpene hydrocarbons } & 6.70 & & 7.30 & & 5.71 & & 5.97 & & 6.85 & & 5.74 & 6.70 \\
\hline \multicolumn{3}{|c|}{ Oxygenated monoterpenes } & 93.32 & & 92.68 & & 94.28 & & 93.53 & & 93.14 & & 94.26 & 93.32 \\
\hline \multicolumn{3}{|c|}{ Total } & 99.81 & & 99.89 & & 99.43 & & 99.45 & & 99.94 & & 99.93 & 99.81 \\
\hline
\end{tabular}

$\mathrm{C} 0$, without compost; $\mathrm{C} 1,50 \mathrm{~m}^{3}$ compost ha ${ }^{-1} ; \mathrm{C} 2,70 \mathrm{~m}^{3}$ compost ha ${ }^{-1} ; \mathrm{T} 0$, zero $\mathrm{TiO}_{2} ; \mathrm{T} 1,2 \mathrm{gL}^{-1} \mathrm{TiO} 2 ; \mathrm{T} 2,4 \mathrm{TiO}_{2}$; $\mathrm{T} 3,6 \mathrm{gL}^{-1} \mathrm{TiO}_{2}$.

Table 4. Relative abundance (\%) of the compounds in seed essential oils of coriander as affected by the treatments of the combination of both titanium dioxide and compost application.

\begin{tabular}{|c|c|c|c|c|c|c|c|c|c|c|c|c|c|c|}
\hline \multirow{3}{*}{ No. } & \multirow{3}{*}{ Compound } & \multirow{3}{*}{ Rt } & \multicolumn{12}{|c|}{ Titanium Dioxide + Compost } \\
\hline & & & \multicolumn{2}{|c|}{ C1T2 } & \multicolumn{2}{|c|}{ C1T3 } & \multicolumn{2}{|c|}{ C2T0 } & \multicolumn{2}{|c|}{ C2T1 } & \multicolumn{2}{|c|}{$\mathrm{C} 2 \mathrm{~T} 2$} & \multicolumn{2}{|c|}{ C2T3 } \\
\hline & & & $\%$ & SD & $\%$ & SD & $\%$ & SD & $\%$ & SD & $\%$ & SD & $\%$ & SD \\
\hline 1 & Sabinene & 3.33 & 0.11 & 0.01 & 0.11 & 0.01 & 0.08 & 0.01 & 0.12 & 0.01 & 0.13 & 0.01 & 0.12 & 0.01 \\
\hline 2 & $\beta$-Pinene & 3.42 & 0.13 & 0.01 & 0.13 & 0.01 & 0.10 & 0.01 & 0.14 & 0.01 & 0.14 & 0.01 & 0.14 & 0.01 \\
\hline 3 & $\beta$-Myrcene & 3.65 & 0.19 & 0.02 & 0.19 & 0.02 & 0.11 & 0.02 & 0.19 & 0.02 & 0.18 & 0.02 & 0.19 & 0.02 \\
\hline 4 & p-Cymene & 4.49 & 4.28 & 0.30 & 4.09 & 0.30 & 3.32 & 0.30 & 2.88 & 0.20 & 2.75 & 0.10 & 4.98 & 0.10 \\
\hline
\end{tabular}


Table 4. Cont.

\begin{tabular}{|c|c|c|c|c|c|c|c|c|c|c|c|c|c|c|}
\hline \multirow{3}{*}{ No. } & \multirow{3}{*}{ Compound } & \multirow{3}{*}{$\mathbf{R t}$} & \multicolumn{8}{|c|}{ Titanium Dioxide } & \multicolumn{4}{|c|}{ Compost } \\
\hline & & & \multicolumn{2}{|c|}{ СоT0 } & \multicolumn{2}{|c|}{ C0T1 } & \multicolumn{2}{|c|}{ C0T2 } & \multicolumn{2}{|c|}{ С0Т3 } & \multicolumn{2}{|c|}{ C1T0 } & \multicolumn{2}{|c|}{ C1T1 } \\
\hline & & & $\%$ & SD & $\%$ & SD & $\%$ & SD & $\%$ & SD & $\%$ & SD & $\%$ & SD \\
\hline 5 & Eucalyptol & 4.68 & 0.05 & - & 0.05 & - & - & - & 0.04 & - & 0.03 & 0.01 & 0.04 & 0.01 \\
\hline 6 & $\gamma$-Terpinene & 5.29 & 1.20 & 0.2 & 1.89 & 0.20 & 1.23 & 0.20 & 1.35 & 0.20 & 1.52 & 0.10 & 1.88 & 0.10 \\
\hline 7 & Linalool oxide B & 5.85 & 0.29 & 0.1 & 0.29 & 0.10 & 0.23 & 0.10 & 0.29 & 0.10 & 0.40 & 0.01 & 0.29 & 0.01 \\
\hline 8 & Terpinolene & 6.05 & 0.09 & 0.02 & 0.09 & 0.02 & 0.05 & 0.02 & 0.08 & 0.02 & 0.08 & 0.02 & 0.08 & 0.02 \\
\hline 9 & Linalool oxide A & 6.35 & 0.13 & 0.01 & 0.13 & 0.01 & 0.22 & 0.01 & 0.66 & 0.01 & 0.26 & 0.01 & 0.66 & 0.01 \\
\hline 10 & Fenchone & 6.41 & 0.22 & 0.01 & 0.22 & 0.01 & - & - & - & - & 0.22 & 0.01 & - & - \\
\hline 11 & L-Linalool & 6.88 & 83.41 & 0.60 & 82.91 & 0.60 & 87.44 & 0.8 & 81.24 & 0.70 & 79.1 & 0.4 & 77.06 & 0.4 \\
\hline 12 & $(+)$-2-Bornanone & 8.41 & 3.09 & 0.12 & 3.59 & 0.12 & 3.31 & 0.12 & 1.67 & 0.12 & 4.55 & 0.12 & 2.68 & 0.12 \\
\hline 13 & Citronellal & 8.63 & - & - & - & - & - & - & 0.03 & 0.02 & 0.13 & 0.02 & 0.03 & 0.02 \\
\hline 14 & endo-Borneol & 9.39 & 0.65 & 0.01 & 0.65 & 0.01 & 0.2 & 0.01 & 0.37 & 0.01 & 0.76 & 0.01 & 0.37 & 0.01 \\
\hline 15 & Terpinene-4-ol & 9.63 & 0.67 & 0.01 & 0.17 & 0.01 & 0.1 & 0.01 & 0.13 & 0.01 & 0.17 & 0.01 & 0.13 & 0.01 \\
\hline 16 & Estragole & 10.39 & 3.02 & 0.20 & 2.52 & 0.20 & 2.24 & 0.10 & 7.76 & 0.10 & 7.46 & 0.10 & 8.76 & 0.10 \\
\hline 17 & $\beta$-Citronellol & 11.85 & - & - & - & - & - & - & - & - & 0.09 & 0.10 & - & - \\
\hline 18 & (-)-Carvone & 12.38 & 0.65 & 0.20 & 0.65 & 0.20 & - & - & 1.92 & 0.20 & 0.59 & 0.20 & 1.92 & 0.20 \\
\hline 19 & Grandlure II & 12.85 & 0.42 & 0.01 & 0.42 & 0.01 & 0.2 & 0.01 & - & - & 0.11 & 0.01 & - & - \\
\hline 20 & Myrtenyl acetate & 15.25 & - & - & - & - & - & - & 0.03 & 0.01 & 0.05 & 0.01 & 0.03 & 0.01 \\
\hline 21 & Geranyl acetate & 17.72 & 0.98 & 0.01 & 1.48 & 0.01 & 0.22 & 0.01 & 0.52 & 0.01 & 0.79 & 0.01 & 0.52 & 0.01 \\
\hline 22 & Dillapiole & 27.73 & - & - & - & - & - & - & - & - & 0.09 & 0.01 & - & - \\
\hline \multicolumn{3}{|c|}{ Monoterpene hydrocarbons } & 6.50 & & 5.97 & & 4.89 & & 4.76 & & 4.80 & & 7.39 & 6.50 \\
\hline \multicolumn{3}{|c|}{ Oxygenated monoterpenes } & 93.08 & & 93.53 & & 94.16 & & 94.66 & & 94.8 & & 92.49 & 93.08 \\
\hline \multicolumn{3}{|c|}{ Total } & 99.58 & & 99.50 & & 99.05 & & 99.42 & & 99.51 & & 99.88 & 99.58 \\
\hline
\end{tabular}

$\mathrm{C} 0$, without compost; $\mathrm{C} 1,50 \mathrm{~m}^{3}$ compost ha ${ }^{-1} ; \mathrm{C} 2,70 \mathrm{~m}^{3}$ compost ha ${ }^{-1} ; \mathrm{T} 0$, zero $\mathrm{TiO}_{2} ; \mathrm{T} 1,2 \mathrm{gL}^{-1} \mathrm{TiO} 2 ; \mathrm{T} 2,4 \mathrm{TiO}_{2}$; $\mathrm{T} 3,6 \mathrm{gL}^{-1} \mathrm{TiO}_{2}$.

\section{Conclusions}

Based on data from the present study, it could be recommended to supply Coriandrum sativum plants with compost at $70 \mathrm{~m}^{3} \mathrm{ha}^{-1}$ in combination with $2 \mathrm{~g} \mathrm{~L}^{-1}$ titanium dioxide to ensure the highest umbel number, seed yield, and essential oil yield.

Supplementary Materials: The following are available online at https:/ /www.mdpi.com/article/10 .3390 / su14010322/s1, Table S1: Physical and chemical properties of the experimental soil at Baluza Research Station, Desert Research Center, North Sinai Governorates, Egypt; Table S2: Chemical analysis of the compost used in the experiment.

Author Contributions: Conceptualization, R.M.R.K., R.M.S. and A.N.G.E.-G.; formal analysis, R.M.R.K., R.M.S. and A.N.G.E.-G.; investigation, R.M.R.K., R.M.S., L.P., A.N.G.E.-G. and A.M.A.-E. writing—original draft preparation, R.M.R.K., R.M.S. and A.N.G.E.-G.; writing-review and editing, R.M.R.K., R.M.S., A.N.G.E.-G., L.P., W.S. and A.M.A.-E.; funding acquisition, W.S. All authors have read and agreed to the published version of the manuscript.

Funding: This research was funded by the Researchers Supporting Project number (RSP-2021/390), King Saud University, Riyadh, Saudi Arabia.

Institutional Review Board Statement: Not applicable.

Informed Consent Statement: Not applicable.

Data Availability Statement: Not applicable.

Acknowledgments: The authors extend their appreciation to the King Saud University, Riyadh, Saudi Arabia for funding this work under Project number (RSP-2021/390). We would like also to express our deep gratitude and grateful thanks to National Research Centre, and Desert Research Center, Egypt for providing facilities and financing this work.

Conflicts of Interest: The authors declare no conflict of interest. 


\section{References}

1. Abdou, M.H.; El-Sayed, A.A.; Ahmed, E.T.; Abdel Salam, A.A. Effect of compost, mineral NPK, effective microorganisms and some vitamin treatments on growth, fruit yield and essential oil content of coriander (Coriandrum sativum L.) plants. Sci. J. Flowers Ornam. Plants 2015, 2, 203-212. [CrossRef]

2. López, P.A.; Widrlechner, M.P.; Simon, P.W.; Rai, S.; Boylston, T.D.; Isbell, T.A.; Bailey, T.B.; Gardner, C.A.; Wilson, L.A. Assessing phenotypic, biochemical, and molecular diversity in coriander (Coriandrum sativum L.) germplasm. Genet. Res.Crop Evol. 2008, 55, 247-275. [CrossRef]

3. Kačániová, M.; Galovičová, L.; Ivanišová, E.; Vukovic, N.L.; Štefániková, J.; Valková, V.; Borotová, P.; Žiarovská, J.; Terentjeva, M.; Felšöciová, S. Antioxidant, antimicrobial and antibiofilm activity of coriander (Coriandrum sativum L.) essential oil for its application in foods. Foods 2020, 9, 282. [CrossRef] [PubMed]

4. Al-Snafi, A.E. A review on chemical constituents and pharmacological activities of Coriandrum sativum. IOSR J. Pharm. 2016, 6, 17-42. [CrossRef]

5. Pathak Nimish, L.; Kasture Sanjay, B.; Bhatt Nayna, M.; Rathod Jaimik, D. Phytopharmacological properties of Coriander sativum as a potential medicinal tree: An overview. J. Appl. Pharmac. Sci. 2011, 1, $20-25$.

6. Momin, A.H.; Acharya, S.S.; Gajjar, A.V. Coriandrum sativum-review of advances in phytopharmacology. Intern. J. Pharmac. Sci. Res. 2012, 3, 1233-1239.

7. Rajeshwari, C.; Shobha, R.; Andallu, B. Antihemolytic activity of various fractions of methanolic extract of coriander (Coriandrum sativum L.) leaves and seeds: A comparative study. Pak. J. Food Sci. 2012, 22, 1-6.

8. Sreelatha, S.; Inbavalli, R. Antioxidant, antihyperglycemic, and antihyperlipidemic effects of Coriandrum sativum leaf and stem in alloxan-induced diabetic rats. J. Food Sci. 2012, 77, T119-T123. [CrossRef] [PubMed]

9. Esiyok, D.; Otles, S.; Akcicek, E. Herbs as a food source in Turkey. Asian Pac. J. Cancer Prev. 2004, 5, 334-339.

10. Adugna, G. A review on impact of compost on soil properties, water use and crop productivity. Acad. Res. J. Agri. Sci. Res. 2016, 4, 93-104.

11. Lal, G.; Vashisth, T.; Mehta, R.; Ali, S. Studies on different organic modules for yield and quality of coriander (Coriandrum sativum L.). Intern. J. Seed Spices 2012, 2, 1-6.

12. Carvajal, M.; Alcaraz, C. Why titanium is a beneficial element for plants. J. Plant Nutr. 1998, 21, 655-664. [CrossRef]

13. Mohammad, M.D.A.; Abdul Kareem, A. Effect of foliar spray with nano titanium, zinc and bulk oxides in some biochemical and active substances of Moringa oleifera Lam. Plant Arch. 2019, 19, 221-227.

14. Lyu, S.; Wei, X.; Chen, J.; Wang, C.; Wang, X.; Pan, D. Titanium as a beneficial element for crop production. Fron. Plant Sci. 2017, 8, 597. [CrossRef]

15. Guenther, E. The production of essential oils. In The Essential Oils, 2nd ed.; Guenther, E., Ed.; Krieger Publishing Company: Malabar, FL, USA, 1972; Volume 1, pp. 87-226.

16. Gomez, K.A.; Gomez, A.A. Statistical Procedures for Agricultural Research; John Wiley \& Sons: New York, NY, USA, 1984.

17. Santhosh, N.; Shankar, R.; Narendranath, R.; Srinivasan, K. Research of production and growth of coriander in various seasons using K-means algorithm. Int. J. Innov. Technol. Explor. Eng. 2019, 8, 518-521.

18. Darzi, M.T. Effects of organic fertilizer and azotobacter and azospirillum bacteria on concentration and composition of essential oil of Coriander (Coriandrum sativum L). Int. J. Agric. Biosyst. Eng. 2015, 9, 1.

19. Said-Al Ahl, H.A.; Khalid, K.A. Response of Coriandrum sativum L. essential oil to organic fertilizers. JEOBP 2010, 13, 37-44.

20. Abd EL-Kafie, O.M.; Ghaly, N.G.; El-Banna, H.Y.; Hassan, A. Effect of Fertilization and foliar applicaion treatments on coriander plant (Coriandrum sativum L.). J. Plant Prod. 2020, 11, 1375-1382. [CrossRef]

21. Mehta, R.; Anwer, M.; Malhotra, S.; Lal, G.; Aishwath, O.; Meena, S.; Kant, K.; Khan, M. Growth and yield of coriander (Coriandrum sativum L)) as affected by sheep manure, vermi-compost and bio-fertilizer. Intern.J. Seed Spices 2011, 1, $22-28$.

22. Kumar, R.; Singh, M.; Kumar, V.; Verma, R.; Kushwah, J.; Pal, M. Effect of nutrient supplementation through organic sources on growth, yield and quality of coriander (Coriandrum sativum L.). Ind. J. Agric. Res. 2015, 49, 278-281. [CrossRef]

23. Vedpathak, M.M.; Chavan, B.L. Effects of organic and chemical fertilizers on growth of coriander crop (Coriandrum Sativum L) Intern. J. Sci. Res. Dev. 2016, 4, 631-634.

24. Vadiraj, B.A.; Siddagangaiah, D.; Potty, S.N. Response of coriander (Coriandrum sativum L.) cultivars to graded levels of vermicompost. J. Spices Aromat. Crops 1998, 7, 141-143.

25. Abd El-Azim, W.M. Effect of compost and number of cuttings on productivity of Coriandrum sativum L. under Sinai conditions. Egypt. J. Desert Res. 2016, 66, 57-68. [CrossRef]

26. Shirkhodaei, M.; Darzi, M.T.; Haj, S.H.M.R. Influence of vermicompost and biostimulant on the growth and biomass of coriander (Coriandrum sativum L.). Intern. J. Adv. Biol. Biomed. Res. 2014, 2, 706-714.

27. Aishwath, O.; Mehta, R.; Lal, G. Effects of on-farm composted seed spices residues on coriander, nutritional parameters and seasonal carbon offset by the crop and soil. Intern. J. Seed Spices 2019, 9, 91-98.

28. Sharangi, A.; Roychowdhury, A. Phenology and yield of coriander as influenced by sowing dates and irrigation. Bioscan 2014, 9 , 1513-1520.

29. Khalid, K.A. Effect of NP and foliar spray on growth and chemical compositions of some medicinal Apiaceae plants grow in arid regions in Egypt. J. Soil Sci. Plant Nutr. 2012, 12, 581-596. [CrossRef] 
30. Sodré, A.C.B.; Haber, L.L.; Luz, J.M.Q.; Marques, M.O.; Rodrigues, C.R. Organic and mineral fertilization in lemon balm. Hortic. Bras. 2013, 31, 147-152. [CrossRef]

31. Ramesh, P.; Singh, M.; Rao, A.S. Organic farming: Its relevance to the Indian context. Curr. Sci. 2005, 88, 561-568.

32. Carrubba, A.; Ascolillo, V. Effects of organic and conventional $\mathrm{N}$-fertilization on quality traits in coriander (Coriandrum sativum L.). Acta Hortic. 2009, 826, 35-42. [CrossRef]

33. Khater, M.S. Effect of titanium nanoparticles $\left(\mathrm{TiO}_{2}\right)$ on growth, yield and chemical constituents of coriander plants. Arab J. Nucl. Sci. Appl. 2015, 48, 187-194.

34. Sayyadizadeh, M.; Bazrgar, A.B.; Bakhtiyari, S. Evaluation of the effects of titanium dioxide nano particles on some morphological traits and oil content of lemon balm (Melissa officinalis L.) under lead stress. J. Sci. Eng. Res. 2016, 3, 532-538.

35. Fazeli-Nasab, B.; Sirousmehr, A.-R.; Azad, H. Effect of titanium dioxide nanoparticles on essential oil quantity and quality in Thymus vulgaris under water deficit. J. Med. Plants By-Prod. 2018, 7, 125-133.

36. Shabbir, A.; Khan, M.; Ahmad, B.; Sadiq, Y.; Jaleel, H.; Uddin, M. Efficacy of $\mathrm{TiO}_{2}$ nanoparticles in enhancing the photosynthesis, essential oil and khusimol biosynthesis in Vetiveria zizanioides L. Nash. Photosynthetica 2019, 57, 599-606. [CrossRef]

37. Khater, M. Effect of $\mathrm{TIO}_{2}$ nanoparticles spraying on fennel plant. J. Plant Prod. 2016, 7, 29-34. [CrossRef]

38. Ahmad, B.; Shabbir, A.; Jaleel, H.; Khan, M.M.A.; Sadiq, Y. Efficacy of titanium dioxide nanoparticles in modulating photosynthesis, peltate glandular trichomes and essential oil production and quality in Mentha piperita L. Curr. Plant Biol. 2018, 13, 6-15. [CrossRef]

39. Missaoui, T.; Smiri, M.; Chmingui, H.; Hafiane, A. Effects of nanosized titanium dioxide on the photosynthetic metabolism of fenugreek (Trigonella foenum-graecum L.). Comptes Rendus Biol. 2017, 340, 499-511. [CrossRef] [PubMed]

40. Rashed, N.M.; Darwesh, R.K. A comparative study on the effect of microclimate on planting date and water requirements under different nitrogen sources on coriander (Coriandrum sativum L.). Ann. Agric. Sci. 2015, 60, 227-243. [CrossRef]

41. Nurzyńska-Wierdak, R. Does mineral fertilization modify essential oil content and chemical composition in medicinal plants. Acta Sci. Pol. Hortorum Cultus 2013, 12, 3-16.

42. Singh, M. Effect of vermicompost and chemical fertilizers on growth, yield and quality of coriander (Coriandrum sativum L.) in a semi-arid tropical climate. J. Spices Aromat. Crops 2012, 20, 30-33.

43. Özyazici, G. Influence of organic and inorganic fertilizers on coriander (Coriandrum sativum L.) agronomic traits, essential oil and components under semi-arid climate. Agronomy 2021, 11, 1427. [CrossRef] 